\title{
11
}

\section{The Lacanian School as an Organizational Structure}

\section{Introduction}

Thirty-five years after his death, the work of Jacques Lacan remains clinically disputed yet theoretically vindicated. The practice of Lacanian analysis is still disputed within IPA institutes who are struggling to reconcile the growing popularity of Lacan and Lacanian analysis with the initial decision that excluded him from the organization. Morever, Lacanian clinical practice may be disputed within IPA psychoanalysis, but this fact is small in comparison to how psychoanalysis at large is clinically disputed within evidence-based practices.

As mentioned in the previous chapter, at some point,

The word psychoanalysis or Freud or Freudian psychoanalysis became a taboo word within the clinic of evidence-based practices. There are many reasons for this being the case despite the fact that nowadays brief psychodynamic psychotherapy has joined the ranks of evidence-based-practices in mental or so-called "behavioral" health.

This chapter has been co-authored by Dany Nobus. 
Although there is empirical evidence that psychoanalysis is effective as a treatment (as argued in the previous chapter), Lacanian psychoanalysis is less disputed within the general culture because it is a new form of psychoanalysis, and science must remain open to new treatments that have not been quantitatively tested.

Lacanian psychoanalysis follows from a different form of rationality and epistemology as already argued. The experience and clinical effect of psychoanalysis is a singularity that can only be verified on a case by case basis and then with difficulty due to the social, ethical, and legal problems involved in disclosing information associated to case histories. The material disclosed in analytical sessions is not limited to social narratives and histories of abuse that could be disclosed to the public and are even disclosed to the public in TV talk shows.

The decline of psychoanalysis is also due to internal reasons, one of which affects Lacanian psychoanalysis and the other does not. The first follows from a dogmatic theoretical position by which we mean not the enumeration of first principles, which is inevitable in science, nor the provision of proofs, but the refusal to consider other schools of thought within or outside psychoanalysis.

The second internal reason for the decline of psychoanalysis affects psychoanalysis but not Lacanian psychoanalysis. Mainstream psychoanalysis remains dogmatic with respect to the frame for treatment which was the main reason for expelling Lacan from the IPA. In this Lacanian psychoanalysis is revolutionary and may coincide with the external critiques of psychoanalysis. The scansion and citation of speech in analysis, and the scansion of the length of the session represent a renewed practice of interpretation that goes a long way in addressing the questioned effectiveness of psychoanalytic interpretations and insight as predictable conscious explanations of the unconscious that are not clinically efficient.

Although Lacan wanted his form of psychoanalysis to take root in North American soil, not only the difficulty of his texts, but also a dogmatic and colonialist attitude on the part of French and European psychoanalysts was not helpful in this regard. What helped establish the first Lacanian School of psychoanalysis in the US (LSP) twenty-six years ago, was the attempt not only to teach Lacanian psychoanalysis 
as a clinical practice, but also to apply Lacanian theory and practice to clinical work in institutions, to use and teach Lacanian theory in local universities, to dialogue with other forms of psychoanalysis, and to accept the local licensing laws for the various professions under which psychoanalysis can take place. At the same time, we are aware that the regulation of the profession can also have an adverse effect on its practice, since the restrictions of the Law do not encourage or support the rule of free association about topics, themes, and fantasies regulated and repressed by the Law. The state regulation of the profession has the effect of generating or enforcing a climate of conformity that may be inimical to the spirit of psychoanalysis.

Nowadays LSP is a functioning Lacanian school in the United States based in California and supporting the practice of Lacanian analysis across the country. Bruce Fink's translations of Lacan's work and Fink's own introductory texts have helped disseminate Lacanian analysis in the United States. Most Lacanian analysts in the US and UK are also licensed and professionally trained clinicians. In the UK, CFAR (Centre for Freudian Analysis and Research) forms clinicians who are then authorized to practice once they finish the requirements for training within the institution. This is a better system than the licensing laws of the US, that require a host of professional bureaucrats, and an industry of experts that live off the regulation of the practicing professional clinician. Given the trajectory of psychoanalysis as a child of Europe, psychoanalysts in Europe were in a better position to mount legal challenges to the attempts by the State to regulate the profession.

In this chapter, we would like to look at the Lacanian school as an organization, beginning with a review of Lacan's trajectory in attempting to develop a new psychoanalytic organization.

Lacan's theories have gone from strength to strength in academic departments of literature, cultural studies, modern languages, linguistics and rhetoric, media and communication studies, women's and gender studies, philosophy and film theory. The versatile applicability of his concepts as solid tools for critical analysis is also demonstrated in the widest range of disciplines outside the traditional human and social sciences, and seems to gain more and more momentum daily, with architects, legal scholars, criminologists, educational 
scientists, theologians and classicists now also engaging with his work (see e.g. Beattie, 2013; Caudill, 1997; Cho, 2009; Hendrix, 2006; Jagodzinski, 2005; Miller, 2007; Milovanovic, 2003).

Since the late 1990s, Lacan's notions have also started to gain momentum in organization research, critical management theory, business studies and public administration scholarship, on both sides of the Atlantic. Many of the new Lacanians in these fields have demonstrated how key Lacanian concepts such as the mirror stage, the divided subject, the objet a, desire, jouissance, fantasy, and discourse can be used productively in order to understand, inter alia, how organizations function and become dysfunctional (e.g. Arnaud, 2002), how individuals operating within organizations maintain their professional identities and develop certain types of working relationships with their colleagues (e.g. Arnaud \& Vanheule, 2007; Driver, 2009b, 2009c; Harding, 2007; Kosmala \& Herrbach, 2006), how authentic leadership is established (e.g. Costas \& Taheri, 2012), how work-related problems such as envy, stress and burnout may be addressed (e.g. Bicknell \& Liefooghe, 2010; Driver, 2014; Vanheule, Lievrouw, \& Verhaeghe, 2003; Vanheule \& Verhaeghe, 2004; Vidaillet, 2007), how strategic and operational change management may be facilitated (e.g. Driver, 2009a; Kenny, 2009), how practices of human resource management affect individuals at work (e.g. Johnsen \& Gudmand-Høyer, 2010), how executive coaching and consulting can be tailored to subjective as well as collective needs (e.g. Arnaud, 2003), how entrepreneurship discourse is predicated upon the assumption of certain "work identities" (e.g. Jones \& Spicer, 2005), how staff representatives react to the threat of factory closure (Vidaillet \& Gamot, 2015), and how organizational processes are conditioned by broader socio-political and economic configurations (e.g. Bloom \& Cederström, 2009; Fotaki, 2009; Glynos, 2011; Stavrakakis, 2008). If Lacan has not fully arrived yet in organization and critical management studies, then he is making serious headway as a theoretical force to be reckoned with.

If we restrict "organizational culture", then, to the classic structure of the corporate enterprise operating under economic conditions of high capitalism, Lacan indeed emerges as the anti-organizational psychoanalytic theorist par excellence. As an anti-humanist and a fierce critic of 
127 the adaptation paradigm in ego-psychology and related psychoanalytic 128 models, Lacan was profoundly weary of any developmental, corrective 129 and accumulative perspective on mental health, and of any clinical and 130 theoretical outlook that regards the restoration of a patient's psychic economy and its return to a well-integrated state of stable equilibrium as a realistic aspiration (see e.g. Lacan, 1988 [1953-1954], p. 25; Lacan, 2006 [1953], p. 204; Van Haute, 2002). By extension, Lacan was extremely sceptical of any social system that inscribes progress and growth as the most advanced accomplishments into its discourse, because he did not believe that the outcomes (goods and services) of a production cycle can be fully achieved through regulatory frameworks (Lacan, 2006 [1968-1969], pp. 15-19).

Obviously, these points would apply to both theory and practice. The ideology of health and well-being is a humanistic approach that is deeply entrenched in the delivery of public mental health services within the United States. Fromm's humanistic psychoanalysis and the humanistic theories of Abraham Maslow and Carl Rogers have been influential in this regard. Lacan would be critical of these developments as having lost the creative edge of the Freudian analysis of the Unconscious.

Ego psychology within psychoanalysis advocates the ego's adaptive, integrative, and synthetic functions that promote a notion of psychical equilibrium within the context of social reality and the reality principle. This approach blends well with psychiatry as a social institution that promotes biological health and normal or normative social behaviour.

What is lost in these approaches is a critical perspective on normal behaviour, and an idealistic/humanistic philosophy serves as a defence against the importance of psychopathology and the symptom for personal development. Lacanian psychoanalysis is centred on the Real of the Unconscious rather than on a humanistic ideal or a historically determined social reality.

However, Lacanians have not abandoned Freud's insistence on the transformations of the symptom and psychoanalysis as a treatment for psychical suffering (applied psychoanalysis). The observations of psychoanalysis, although empirical and clinical, are singular and apply to each subject in which psychoanalysis is reinvented as a practice and a 
theory. Clinical outcomes can be measured according to symptom index scales in the areas of work and relationships. However, Lacan did abandon measuring psychoanalytic outcomes based on the ability to maintain relationships as is commonly the case within mainstream psychoanalysis and psychiatry (DSM's social and occupational objectives). If anything, social outcomes of treatment nowadays have to take into account the realities of relationships in contemporary society where many marriages end in failure and where Freud's developmental ideal of joining love and the sexual drive no longer holds.

What replaces the notion of a normative relationship is the realization that the human problem of an ideal rapport between the sexes does not exist. People may choose to make do or not with whatever relationships in which the sinthome may be implicated. In addition, the other side of the failure of the rapport between man and woman (male or female), is the proposition that "Il y a d'Lun" (the One 'ex-sists'). A singular subject may find equilibrium not in a relationship but in being "All-alone". This is not a narcissistic isolated individual but rather a singular subject linked to others through symbolic links and the Real that forges them. If Lacan has a developmental ideal it is through the subject of the Real of his later work that makes accord or creates new links and a new Borromean structure.

In line with this, Lacan did consider how the "anti-organizational" forms of lack, loss, and waste could be built into the walls of an alternative organization, how organizational life could be re-built, as it were, upon the foundations of incompleteness, as a non-totalizing entity in which hierarchical authority is balanced against a communal, libertarian and solidarity culture of exchange.

\section{Esprit de Corps}

In the late Summer of 1945, Lacan spent five weeks in England, during which period he visited Hatfield House in Hertfordshire, which at the time was a specialized centre for the rehabilitation of former prisoners-of-war and veterans. Still a psychiatrist, yet also already a psychoanalyst, what Lacan saw at Hatfield made a huge impression on him, 
196 so much so that upon his return to Paris he showered heaps of praise on this quintessentially English version of "democratic psychiatry"... Psychiatry served to forge the instrument thanks to which Britain won the war; conversely, the war has transformed psychiatry in Britain" (Lacan, 2000 [1947], pp. 26-27).

Even more instructive than his visit to Hatfield was Lacan's long conversation with Wilfred R. Bion and John Rickman - "two men", he said, "of whom it can be said that the flame of creation burns in them" (ibid.: 15). During the Winter of 1942-'43, Bion had been put in charge of the rehabilitation of demoralized soldiers in the so-called "Training Wing" of the Northfield Military Hospital, near Birmingham (Harrison, 2000, p. 186).

Rather than reinforcing the Wing's iron army discipline, and actively preparing the soldiers for their swift return to military service, which had often seemed to result in an exacerbation of their neurotic symptoms, Bion helped the men re-focus their energies on the accomplishment of specific group tasks and the management of inter-personal relationships. Rather than treating the soldiers' neurotic conditions as individual illnesses, Bion decided to turn neurosis itself into the collective enemy, thus re-creating a positive esprit de corps characterised by shared loyalty, solidarity, fellowship, and an implicit sense of duty amongst the patients who became willing to accept responsibilities.

Lacan thought this so-called "first Northfield experiment" to be absolutely brilliant. Speaking to L'évolution psychiatrique, he stated: "[T]he lively details of this experience [...] seem to me to be pregnant with a birth of sorts that is a new outlook opening upon the world" (Lacan, 2000 [1947], p. 19). But he did not stop there. Apart from complimenting the way in which English psychiatrists had succeeded in tackling the problem of war neurosis in new and imaginative ways, Lacan also applauded Bion's so-called "leaderless group project", which had been conducted some years before the first Northfield experiment, under the auspices of the War Office Selection Boards. As Bion put it, during the experiment "it was the duty of the observing officers to watch how any given man was reconciling his personal ambitions, hopes and fears with the requirements exacted by the group for its success" (Bion, 1946, p. 78). 
Neither the observing officers, nor the advising psychiatrists, nor Bion himself for that matter, were acting upon a position of authoritarian leadership, but rather "suspended" their leadership in favour of releasing the group's own internal dynamics, thus also questioning its propensity to expect shotgun solutions to be delivered by identified leaders. Reflecting upon the experiments and justifying the idea of "suspended leadership", Bion later commented: "The group always make it clear that they expect me to act with authority as the leader of the group, and this responsibility I accept, though not in the way the group expect" (Bion, 1961 [1948-1951], p. 82). In his subsequent work with groups, Bion would consistently refuse to adopt a directive stance, instead allowing the group to evolve spontaneously and to follow its own internal laws, and only intervening when he believed he knew what was about to happen, which often left people in the group feeling puzzled and bemused.

Lacan strongly commended how English psychiatrists had made a major contribution to the war effort, but he was even more appreciative of the "democratic" principles supporting Bion's innovative recruitment device.

Firstly, rather than someone in an established position of authority recruiting and selecting the new officers, candidates are being given the opportunity to demonstrate in vivo what they are worth, and therefore to somehow self-select, in a situation of strict "fair play". Secondly, although the officers and psychiatrists assess individual contributions to the group task, they themselves only testify about what they have observed to a selection panel, so that theirs is only one voice among many, and the final decision is to a large extent based on what is conveyed in a "witness statement".

Thirdly, the objectivity and validity of the entire process are not driven by the controlled administration of psychometric tests or the use of conventional quantitative measures of physical and mental capacity, but rather by the careful elicitation and rigorous evaluation of strictly subjective phenomena (Lacan, 2000 [1947], pp. 22-24). It is these very principles that Lacan would endeavour to situate at the heart of the psychoanalytic training programme in the Ecole freudienne de Paris (EFP), the organization which he himself founded in June 1964, some eight months after his exclusion from the International Psycho-Analytic Association (IPA). 


\section{Work Transference}

Neither in his written texts, nor in any of his seminars did Lacan explicitly refer to Bion's work again, yet his most important contribution to organizational theory, namely his own foundation of the EFP and the fundamental pillars upon which it was built, was clearly inspired by Bion's experiments with leaderless groups and at Northfield. It should be mentioned, in this context, that up until the point when the EFP was established, Lacan had had a fair share of trouble with psychoanalytic institutions, not in the least with the IPA, from which he was definitively barred as a training analyst in November 1963 (Miller, 1977; Turquet, 2014).

The key events are worth recapitulating, here, if only because they once again illustrate that, contrary to what some scholars have claimed, Lacan had a lifelong interest in organizations, clearly positioned himself vis-à-vis a certain type of organizational culture, and typically argued in favour of an organizational structure that is commensurate with the nature of the task to be accomplished.

In 1934, whilst still in analytic training, Lacan joined the Société Psychanalytique de Paris (SPP), then the only psychoanalytic organization in France, and rapidly made his way through its ranks, becoming a full member in 1938 (Roudinesco, 1997 [1993], pp. 80, 86). When, after the second World War, the SPP resumed its activities, Lacan became a member of the SPP's "Teaching Committee" and in this capacity, he produced a paper outlining the procedures for the selection of new trainees, as well as the indicative contents of a psychoanalytic training programme, and the mechanisms for recognizing new psychoanalysts (Lacan, 1976 [1949]). The document was mainstream apart from the fact that Lacan did not de facto wish to exclude non-medically trained candidates from the psychoanalytic profession, and that he also proposed a certain de-centralization of power, allowing more members to participate in decision-making processes pertaining to candidate-selection and the delivery of teaching.

Then, during the Winter of 1952-'53, an acrimonious conflict erupted between Lacan and Sacha Nacht, the president of the SPP, around the organizational structure of a proposed psychoanalytic Training Institute, 
whereby Lacan's main reservations concerned the seemingly unassailable power of the Institute's directorate and the autocratic "examination" of the candidates' training by a sovereign group of self-appointed "officials". In the end, Lacan lost out and was forced to resign from the SPP, by which he also forfeited his membership of the IPA (Miller, 1976, p. 90). The minutes of the IPA business meeting of July 1953 indicate that Lacan's vehement attack on the Institute's hierarchical functioning may not have been the only problem, and that Lacan was also perceived as someone who would take unacceptable liberties with firmly established clinical rules. As Marie Bonaparte, by far the most prominent member of the SPP, put it to the IPA committee: "[O]ne of these members [Lacan] [...] promised to change his technique [of variable-length clinical sessions], but did not keep his promise" (Eissler, 1954, p. 272).

After the first split in the French psychoanalytic community, Lacan spent ten years delivering his weekly seminar at Sainte-Anne Hospital, as part of the analytic training programme of the newly created Société Française de Psychanalyse (SFP), whilst practicing as a psychoanalyst, entertaining people at his Summer house in Guitrancourt, and generally having fun. At the SFP, he did not occupy any important administrative or managerial positions, yet generally supported the new organization's request to be considered for re-admission to the IPA (Etchegoyen \& Miller, 1996, p. 48).

However, throughout this period, Lacan also fired on all cylinders when considering the psychoanalytic establishment's practices and procedures, whereby he did not let an opportunity go by to ridicule the institutional hierarchy and its rigid, dogmatic attitudes towards analytic practice and training standards. Already in the 1953 "Rome Discourse", he suggested that the SPP's Training Institute was erected based on a "disappointing formalism that discourages initiative by penalizing risk and turns the reign of the opinion of the learned into a principle of docile prudence in which the authenticity of research is blunted even before it finally dries up" (Lacan, 2006 [1953], p. 199). With undisguised sarcasm, he went on to compare the Institute's conception of analytic training to 'that of a driving school which, not content to claim the privilege of issuing drivers' licenses, also imagines that it is in a position to supervise car construction' (ibid.: 200). 
Lacan's finest moment came in 1956, in a paper published on the centenary of Freud's birth. Dissecting the so-called "situation" of psychoanalysis and the contemporary condition of psychoanalytic training programmes, he painted a hilarious satirical picture of the spurious distribution of power in the psychoanalytic establishment, in the great tradition of Swift and Rabelais. In "The Situation of Psychoanalysis and the Training of Psychoanalysts in 1956" (Lacan, 2006 [1956]), which remains one of Lacan's least studied papers, but also one of his most vehement repudiations of the hierarchical structure of (psychoanalytic) organizations, he designated those people who are in analysis as Little Shoes.

Little Shoes comply with institutional and clinical rules, do not dare to speak up for themselves outside the sessions, and generally follow the path imposed by the soi-disant or 'Sufficiencies', those who have successfully finished their analytic training and have been given full access to the psychoanalytic profession-psychoanalysts, as the Institution would call them. Lacan asserted that the Sufficiencies do not say much either, because self-sufficient as they are they do not feel the need to start a conversation or engage in discussion.

But then there are also the 'Beatitudes', in whom we can easily recognize the so-called "training analysts", and who have been appointed by the Sufficiencies, and put in charge (as superior members of the organization) of the Truly Necessary, i.e. those Little Shoes who do not come to see a psychoanalyst because they want to be relieved of some pressing personal problem but because they want to train as psychoanalysts.

In carefully laying out the stakes of his elaborate exposition, Lacan conceded that no psychoanalytic society can exist without Sufficiencies (practicing psychoanalysts), with the caveat that as a professional rank this position can only ever be reached asymptotically and therefore never be fully attained, so that Sufficiency is but the momentary occupation of a certain clinical position and not the definitive realisation of a certain professional stature. Put differently, for Lacan, analytic training is never fully finished, and no one should ever have the right or the duty to say that he or she is or has effectively become a psychoanalyst.

Critical as the presence of Sufficiencies may be for the survival of psychoanalytic organizations, Lacan was particularly disapproving, here, 
of the sovereign power they seem to have, not only in selecting the Truly Necessary (analytic trainees) and distinguishing them from the Little Shoes, but also in appointing the Beatitudes (training analysts) from their own kind, and deciding which of the Truly Necessary can become Sufficient on the basis of what the Beatitudes have managed to achieve with them. In short, Lacan disputed the doctrinal authority with which the psychoanalysts in the organization would concentrate all power within their own ranks, and exposed the psychoanalytic establishment as a ritualized, ceremonious and formulaic institution, not dissimilar to the self-perpetuating leadership of the Catholic priesthood or religious organizations.

Less than two months after Lacan was expelled from IPA and SPP he started again with a new seminar, in a new location and with a new audience. The topic was "the foundations of psychoanalysis", later to be modified into "the four fundamental concepts of psychoanalysis". At the beginning of the first lecture he could not resist reopening a barely healed wound, and so he started with the question "En quoi $y$ suis-je autorisé?"- "What gives me the authority to do this?" or, as the English translator of the seminar renders the phrase: "Am I qualified to do so?" (Lacan, 1994 [1964], p. 1). Clearly, the problematic "authorization" in question did not simply concern Lacan's position as a lecturer but referred more specifically to his teaching about the foundations of psychoanalysis.

The question should thus be understood as: "What authorizes a psychoanalyst who has just been officially removed from his training position in a psychoanalytic organization to lecture on the basic principles of his discipline?" If the question was not entirely rhetorical, Lacan nonetheless decided that the "problem [be] deferred" (ibid.: 1). But not for too long. At the Summer solstice of 1964, Lacan created his own School, the École Française de Psychanalyse (EFP), subsequently to be renamed as the École freudienne de Paris. In the opening paragraphs of its "Founding Act" he emphasized that the organization ('organisme) had been established to accomplish a programme of work (un travail), with three distinct aims: (1) restoring the cutting-edge truth of Freud's discovery; (2) returning the practice of psychoanalysis to its proper

(3) denouncing the deviations and compromises 
411 that blunt and degrade psychoanalysis (Lacan, 1990 [1964], p. 97).

412 Although he did not refer to Bion's distinction from the early $1950 \mathrm{~s}$ 413 between a productive work group and three inert basic-assumption 414 groups (Bion, 1961 [1952]), Lacan thus set out with the explicit goal 415 of forming a "work group", whose working objective or primary task 416 (objectif de travail) consisted in a "movement of reconquest" (mouvement de reconquête) (Lacan, 1990 [1964], p. 97).

To ensure that the group would remain focused on the designated task and would not (as Bion would have had it) resort back to one or more "basic assumptions" (fight or flight; pairing or tactical political alliances against this or that; or idealization of a leader), Lacan proposed that the work be carried out by small groups of minimum three and maximum five people, and an additional person-the so-called "plus one"-who oversees selecting the concrete work topic, facilitating the discussion and determining the outcome of each individual group member's work (ibid.: 97). After some time, the small groups would be expected to permute, insofar as the individual members would be encouraged to leave to join another group. Lacan decided to call the small group a "cartel" - a name he glossed etymologically as being derived from the Latin cardo, meaning "hinge" (Lacan, 1990 [1964], p. $101 ; 1976$ [1975], p. 221). It is important to note, here, that the cartel constitutes a temporary collective effort around the accomplishment of a set of specific individual tasks, from which the entire organization may benefit.

Being a member of a cartel (the essential work group) was also a necessary and sufficient condition for being a member of the School (Lacan, 1990 [1964], p. 100). In addition, Lacan stipulated that whoever is put in charge of "directing", be it the work of the cartels or (at a higher level) the work of the entire School, would not be occupying a chiefdom (chefferie), because of which he or she would then be given access to a higher rank. Mutatis mutandis, nobody in the School, regardless of rank and status, would be perceived as having been demoted if she or he engages in "base-level work" (ibid.: 97-98). Every individual enterprise (enterprise personnelle), regardless as to which position the individual occupies within the School, would moreover be subjected to institutional criticism and control, so that no hierarchical stratification 
makes someone inferior or superior, and a "circular organization" (organisation circulaire) is created (ibid.: 98).

The idea of the cartel was exceedingly simple and is redolent of the leaderless groups Bion set up when having to select new Army officers at the start of the second World War, with the proviso that in Lacan's School the cartels were not designed to select or recruit individuals, nor to facilitate any kind of therapeutic results, but to contribute to the accomplishment of the School's primary task. As such, the Lacanian cartel drew both on the leaderless group and Bion's "work group", whereby institutional leaders are placed in positions of "suspended" authority.

Although the concept and structure of the cartel was discussed extensively in the EFP, it did not prove nearly as controversial as Lacan's proposals for safeguarding the quality of the work and guaranteeing its transmission. If the cartel is the format and the mechanism by which the work is executed, then a certain regulatory framework is required to ensure that the work is captured, evaluated and communicated, internally as well as externally. What is required here, Lacan stated, is a "work transference" (un transfert de travail), which requires putting in place a system that enables the work to be transferred from one person to another, from one group to another, from the groups to the School, and from the School to its external environment (ibid.: 103). The notion of transfert de travail may very well be a hapax in Lacan's work, but should clearly be understood in connection with what, in his 1958 text on the direction of the treatment, he had already defined as travail du transfert (the work of transference) and travail de transfert (transference work), both terms adduced as translations of Freud's concept of Durcharbeitung (working through), which is meant to capture the most advanced part of the clinical psychoanalytic process (Freud, 1914, p. 155; Lacan, 2006 [1958], pp. 498, 526).

The two notions of the work of transference and transference work are two different notions that can be mistaken for one another. The same applies to the notion of transference love and love's transference in Freud. Transference is present in all relationships but has a technical meaning in the therapeutic relationship between analyst and analysand. The same is true of work transference and transference work. The 
483 first refers to the transference of work and of goods from one person to another in the work of the organization.

Transference proper is the transference of the Unconscious of the analysand (mainly sexual and aggressive fantasies, traumas, etc.) unto the analyst who does something different with it than what happens in human relationships. Transference in analysis is something problematic (that could even derail the treatment) that does not necessarily help the treatment. If anything, and as Winnicott pointed out, the analyst must survive the transference. This is clearly not the case with work transference within an organization although there can be a residue or transference work at work within work transference that threatens a psychoanalytic organization from within. Many personal transferences get acted out in the work of the organization as a communal structure and alleged democratic institution.

Traditionally, psychoanalytic institutions had guaranteed the transmission of their work, which in this case refers both to how psychoanalytic knowledge is being passed on generally, as well as to how new psychoanalysts are being trained, via a strict set of rules and regulations, controlled by an "executive board", which sits at the top of the institutional hierarchy. Possibly inspired by what he had observed in England during the Autumn of 1945 and emboldened by what he himself had experienced in his tumultuous relations with representatives of the SPP and the IPA, Lacan decided to organize his own School in a radically different way, although for many of its members this would prove to be an unfeasible, potentially deleterious initiative.

\section{Dissolution}

Working from the basic axiom that a psychoanalytic institution cannot function without psychoanalysts, Lacan came up with the provocative claim that a psychoanalyst derives his authorization only from himself (le psychanalyste ne s'autorise que de lui-même) (Lacan, 1995 [1967], p. 1), by which he meant that only someone's own analytic experience, i.e. the analysis that someone has undertaken, can equip him or her with the necessary "qualifications" to practice psychoanalytically, 
and not the successful completion of a "pseudo-academic" training programme, let alone the endorsement by an institutional hierarchy.

Although many people (mis)interpreted this principle as Lacan effectively suggesting that anyone should have the right to call himself a psychoanalyst-with potentially disastrous consequences for the clinical standards, the public image and the future of the discipline-in practice he argued in favour of the recognition of one single criterion for evaluating whether someone could be considered a psychoanalyst, and be authorized to practice: the personal experience of having been through the process of psychoanalysis.

Nonetheless, when presenting this principle to the EFP in October 1967, Lacan also considered the possibility of the School formally recognizing that someone had effectively been trained as a psychoanalyst and was working psychoanalytically, whereby he outlined two avenues for this recognition. First, the School may decide to bestow the title of "Analyst Member of the School" (AME) upon those practicing psychoanalysts who have demonstrated their analytic ability, in whatever form, and without the psychoanalysts themselves asking for this recognition. Second, analytic trainees and practicing analysts may themselves ask for institutional recognition, in which case they are required to speak about their own psychoanalytic journey, individually and independently, to three "passers"-members of the School who are roughly at the same point of their own trajectory and therefore "equals"-who subsequently transmit what they have heard to a decision-making body (the so-called "cartel of the pass"), which then deliberates as to whether the candidate should be given the title of "Analyst of the School" (AE) (Lacan, 1995 [1967], p. 1).

Lacan made it clear that these titles should not be interpreted in a hierarchical way, as the AMEs being superior to the AEs, or vice versa, but simply as different "steps" (gradus), each with their own duties and responsibilities. At the same time, he also reduced the power traditionally accorded to the training analyst, since he no longer wished to differentiate between a training analysis and a "regular analysis". Lacan did not see the need for potential analytic trainees to be treated differently from "normal patients" and did not want the training analysts to have the power to decide, or even to advise on how and when trainees should be recognized as psychoanalysts. In this non-hierarchical structure, and 
the radical decentralization of institutional power that Lacan attempted to bring about, here, we can once again detect an echo of Bion's ground-breaking experiments with leaderless groups.

The recruitment and selection of new psychoanalysts was not left to people in a position of authority, but candidates were able to self-select, insofar as they simply draw on their own analytic experience to apply their skills, demonstrate their capacity or satisfy independent observers. Much like the selection panel had operated in Bion's leaderless group experiments, the actual decision-making body does not evaluate the candidates directly but relies for its judgment on a set of non-partisans "witness statements". What matters is not whether someone has passed a requisite number of tests with flying colours - say a portfolio of examinations and coursework and the minimum amount of analytic sessions with a training analyst-but whether someone's subjective analytic experience shows sufficient clinical promise for that person to practice psychoanalytically.

So, did it all work? Because Lacan decided to dissolve his own School some fifteen years after it was created, one may be tempted to respond with a resounding "no". However, much like the Stalinist atrocities may not in themselves be a sufficient reason for confirming the intrinsic failure of the great communist experiment, Lacan's dissolution of the EFP may not as such be a reliable indicator of the fact that the entire organizational edifice was built on extremely loose foundations.

Despite Lacan's well-meaning attempt to diffuse institutional power, the EFP did not live up to the grand expectations that were raised on the day of its first inception. In transforming traditional hierarchical patters of operation into a "circular organization", Lacan was firmly convinced that the work of the School could be accomplished, and that doctrinal inertia could be averted, yet the institutional "consistency" that he believed would come with experience did not materialize, or gradually transformed itself again into a more conventional series of arrangements, with teachers and pupils, thinkers and disciples, leaders and followers, masters and servants.

The problem, no doubt, was to a large extent Lacan himself, who would always be the superior "plus one", the one who would not only stand out from the others because having been the one to found the 
School (and therefore also being the only one who could subsequently legitimately disband it), but the one who was de facto intellectually unassailable, clinically infallible, institutionally unimpeachable.

Much like Bion in his Northfield experiments, Lacan recognized that the School expected him to demonstrate his authority as the leader of the organization in his capacity of Director of the School. Much like Bion, he accepted this responsibility, without therefore always complying with what the group was expecting of him. Yet this position of "suspended leadership", which constitutes an alternative position of agency-closer to that operating within the discourse of the analyst than that which is at work in the discourse of the master, following the distribution of functions in Lacan's famous "theory of the four discourses" (Lacan, 2007 [1969-1970]—gradually changed into a new, uncritical attribution of power.

Lacan's innovative mechanism for securing the institutional recognition of psychoanalysts who wish to be recognized as such, which came to be known as the "procedure of the pass", gradually showed its fractures. Witnesses were not believed to be as non-partisan and independent as could be hoped for. Testimonials were believed to be contaminated by the witnesses' knowledge of the identity of the candidates' own psychoanalysts. New artificial hierarchies started to emerge, and the work transference did not always manifest itself as creatively and productively as Lacan had wished for.

In a letter of 5 January 1980, Lacan announced that the School he had created some fifteen years earlier would be dissolved (Lacan, 1990 [1980]). One could no doubt see Lacan's decision, here, as an act of despair or frustration, or as an act signalling his own admission of organizational failure, yet one could also interpret it in a different light, as the intentional initiation of necessary transformational change. In the opening paragraphs of his letter, Lacan reminded his readership of the main reasons as to why he had decided to create the EFP: "[F]or a labor [...] which in the field opened by Freud restores the cutting edge of his $\mathbf{1 0 3}$ truth-which brings the original praxis he instituted under the name of psychoanalysis back to the duty incumbent upon it in our world. "I maintain [this objective]", Lacan posited, and that "is why I am dissolving" (ibid.: 129-130). Hence, the dissolution of the organisation is a 
624 necessary precondition for the work towards the accomplishment of the primary task to be sustained. For the "circular organization" to survive, it must occasionally be dissolved and re-created, especially at a time when it seems to have reached a standstill, and when the members may be least expecting (or wanting) it, owing to the installation of a certain professional and socio-intellectual comfort.

Like the work-group that is the cartel, the "circular organization" has its life-span and must be disbanded, permutated and re-constructed to sustain itself as such. On 11 March 1980, towards the end of his last public seminar, Lacan invited the former members of his School to mourn, which also constitutes a kind of work, the death of their institutional home, and to become "de-Schooled" and "de-glued" (d'écolé), whilst at the same time announcing that a new organizational structure would be created, with the same structure of small working groups at its basis (Lacan, 1982 [1980], p. 87). If the esprit de corps, had been adversely affected by the work transference and enactments of transference work within the organization, this necessitated the dissolution of the School, and no dissolution should stand in the way of the re-creation of a new esprit de corps.

\section{The Viability and Future of the Lacanian School}

\section{as a Psychoanalytic Organization}

As a theorist critical of psychoanalytic institutions, Lacan occupied himself with the recruitment and selection of candidates (for psychoanalytic formation), with the way in which (psychoanalytic) formation is delivered and monitored, with how the end of the formation process should be conceived, with how candidates who have finished their training should be recognized institutionally, and with typical "managerial" processes of (analytic) appraisal, evaluation and promotion. He was concerned about the stratification, the hierarchical structure, the allocation of authority, the distribution of power and the function of leadership in (psychoanalytic) institutions. He was deeply involved in setting the parameters for assuring institutional quality and standards, guaranteeing the organization's normative primary task, and securing its social and epistemological sustainability. 


\section{R. Moncayo}

Despite Lacan's critique of the organizational structure of psychoanalytic institutions, and despite following Bion's experience with leaderless work groups and having the leader function in a state of suspended authority (an organizational model that Bion did not apply to the British Psychoanalytic Society), Lacan's reformations never completely deviated from the three functions that Eitingon (1922-1925) originally assigned to a psychoanalytic clinic: therapeutic, formative, and research. Lacan's school formed psychoanalysts, practiced psychoanalysis, and engaged in research and publication of written work.

In addition, in the Founding Act of his school Lacan emphasized denouncing the deviations and compromises that blunt and degrade psychoanalysis. This aim is not that different from the aim outlined by the the International Psychoanalytic Conference of 1925 that

sought to prevent the premature amalgamation and synthesis of psychoanalysis with other fields, research methods, and clinical practices. Given Freud's several initial problems with students who dissented/deviated from his teaching, the early international psychoanalytic movement was concerned with preserving and preventing the destruction of Freud's theory and practice. (idem, p. 223)

\section{Moreover,}

The process of increased institutionalization and standardization of authority within psychoanalysis generated criticisms and questioning from the very beginning. Hans Sachs (Safouan, 1995) pointed out that wherever there is organization and hierarchy, the discovery of the new, and the possibility of change and transformation, becomes suppressed and repressed. Every institution is conservative in nature, and aims at its own survival and self-preservation and, therefore, has low tolerance for creative and inventive minds and subjects. (Moncayo, 2008, p. 224)

This would certainly apply to Lacan as an outstandingly creative and inventive psychoanalyst who thought that hierarchy and standardization was blunting the creative edge of psychoanalysis. Nevertheless, it remains unclear whether Lacan's organization succeeded in replacing traditional hierarchies, since even in the Pass procedure, the 'passers' 
690 introduced their own distortions to what was heard from the analysand and eventually a committee of analysts of the school decided whether a proper analysis had taken place. So, the hierarchy was maintained and produced two different class of analysts: those who passed the pass and those who did not but are still practicing analysts. Obviously given the structure of the organization, analysands would tend to choose analysts from those who had passed the pass.

Although the personal analysis is the necessary bedrock of analytic training, the question remains whether the personal analysis is sufficient criterion for the formation of psychoanalysts. A psychoanalyst of the school serves the public by offering psychoanalysis to those Lacan calls 'Little Shoes,' but a psychoanalytic organization requires candidates who enter the school to become psychoanalysts and need a personal analysis as part of this process (the Truly Necessary for the school).

However, Lacan always emphasized that a didactic analysis for purposes of formation was always a personal analysis like any other. In fact, an applicant should not be accepted into formation if they cannot present a symptom for analysis and instead view a personal analysis as a didactic process to learn the theory and practice of analysis (The Truly Necessary must be Little Shoes first).

At the Lacanian School of Psychoanalysis of the San Francisco Bay Area we followed Safouan (an early student of Lacan) in continuing the practice of control analysis or supervision as a necessary component of analytical formation (Safouan, 2000). Control analysis is second in importance but is not a replacement for the personal analysis. Lacan was concerned that the regulated supervision of the practice of analysis could become an organized resistance to the personal analysis and the work with the unconscious.

During the 1974 Rome Congress of the E.F.P. (the Freudian School of Psychoanalysis), a consensus was building in the Lacanian field that, supervision, as a bureaucratic requirement, institutionalizes a resistance to analysis. Supervision, as an institutional requirement of so many certified years and hours, functions as an obsessional defense against dealing with difficulties inherent to the practice of analysis and the field of transference. Lacan believed that obligations with regards to the position of 

having decided to do or not to do something. (idem, p. 29)

LSP made an early decision to require that analysts adhere to the licensing laws of California for the various professions. A license is the product of an alliance between the master's discourse or the discourse of government and the university discourse used to regulate government, business, and professional practice. A license does not authorize an analyst to practice psychoanalysis. In fact, since licenses do not require a personal analysis, all the regulations involving supervised experience miss the boat as to what guarantees best results for a member of the public benefitting from psychoanalysis.

When people approached Lacan for control he would refer them to analysis. Of course, this can vary if the person is a candidate of the school or the person already is in analysis or already had an analysis. The point here is that analysis is the first principle of formation, not that it's the only one.

There are forms of professional and even psychoanalytic practice for which formation does not require a personal analysis. An example would be the practice of psychoanalytic psychotherapy where supervision, for example, becomes an analysis of the countertransference as projective identification from the analysand to the analyst.

The point is not to critique various professional perspectives, but rather to understand, in our current context, how Lacan may have been responding to a demand for supervision as a demand for analysis or even as a resistance to analysis.

In any case, what is a control analysis or supervision of psychoanalysis (to use arbitrary semantic terms for a moment without delving too much into the limitations of their literal meanings)? Supervision has always existed alongside the personal analysis in psychoanalytic institutions, sometimes with the same analyst but more likely with two different analysts. As we shall see, control and supervision are both arbitrary deficient terms to describe an analytical state of suspended authority. A control analyst neither controls nor has 'super-vision' like superman. If anything, control analysis is a form of 'other-audition': what the analyst hears in what the analyst heard of the analysand's speech that the candidate 
760 analyst does not know that they know. This is what Reik (1998) called listening with the Third ear. The Third is the place where the sense organ and the object of sound meet savoir or unconscious knowing or a form of un-self-conscious-knowledge (a form of subjective objectivity).

The control analyst also helps a candidate analyst articulate or put into use the theory in relationship to the practice of analysis. In addition, it is also implied that a candidate analyst participates in seminars, case conferences, and the study of psychoanalytic theory and practice as fundamental aspects of analytical formation.

These two practices (personal and control analysis) plus the study of the theory constitute the triptic of psychoanalytic education and formation. But ultimately for Lacan the analyst is authorized by their own symptom become sinthome in life and the personal analysis. At the same time the entire organization stands on the subject's desire as the motivating factor. At LSP candidates have a responsibility to keep the record of what they have done by way of meeting the requirements of the School. The record is a testament to their desire for analysis and professional formation. This minimizes the bureaucratic dimension and at the same time prevents that formation simply become a demand of the Other, or a discourse of the master, or the discourse of the university. Although Lacan declared that the Pass procedure had failed he

Lacan never gave up the idea of the privileged role of the personal analysis for the practice of analysis but he did give up trying to evaluate it in any kind of institutional or objective fashion. Instead he turned his attention to the theoretical question of the sinthome as what ultimately authorizes an analyst. (idem, p. 31)

However, although standarization or objective evaluation of analysis is ultimately impossible, there are criteria by which to determine if an analysis is taking place in the proper sense of the term. For example with regards to the transference to the 'subject supposed to know (sujet AQ4 suppose savoir) two things need to take place: (1) A positive transference needs to established; (2) The analyst has to remove himself/herself from the position of the subject supposed to know without losing the positive transference that allows the Ucs. of the analysand to manifest. 
When the positive transference is established the analyst says very little to the analysand and approves most of what they say, except in extraordinary circumstances, of course. The analyst accepts the defenses that the ego uses to describe their problems and hears the saying that emerges in the space between words and within the narrative statement (the said).

The positive transference cannot be described as a desire of the analyst to be liked because otherwise this would be transference and something that the analyst had to work out in his/her own analysis. In fact, the desire of the analyst not to be idealized in the transference supports the strength of the positive transference and can be considered a fruit of the personal analysis. The positive transference is not a response to the desire to be liked and loved but rather to a strategy of savoir and a question of correct method. The desire to be liked and admired is a characteristic of the histerical master in the formula for the master's discourse: $\frac{S_{1}}{\$} \rightarrow \frac{S_{2}}{a}$. The master's lack demands that subjects/servants locate the objet $a$ in them.

The social organizational consequence of the first criterion to carry out or evaluate an analysis, is that the analyst accepts the leadership of the position but then uses it in a different way. This different use is the relinquishing of the position of SsS, a veritable symbolic castration of the position of the master that transforms the position from a master position to an analytical position. This is the democratic principle that Lacan envisioned. A free association that permits the Unconscious or the unconscious signifying chain and the Real to emerge. The analyst is an $S_{0}$ instead of the $S_{1}$ of the master. The $S_{0}$ is the objet $a$ in the place of the agent in the formula for the analyst's discourse. The analyst moves from the position of the beloved imaginary object ( $a$ /phallus), to the position of the absence or emptiness of the objet $a$.

But what authorizes an analyst? Lacan (1967) famously stated that $\mathbf{Q 0 5}$ the analyst is authorized by himself/herself and then he added and a few others. What does this mean? It does not mean that an analyst is self-taught and self-appointed as an analyst without any psychoanalytic formation or association to a Lacanian school. From this point of view self-authorization on the basis of a personal analysis alone or on the basis of a professional degree or license could be equally problematic. 
Sometimes people may combine these elements on their own (including attendance to seminars or study groups) in which cases a school may accept those analysts (as well as others trained in other analytic organizations) as Analysts Member of the School so long as they support the School and its principles. The Analyst of the School is still necessary since the reference to the barred Other of the school allows for the transmission and articulation of the triptic of analytical formation (analysis, control, and savoir). However, at LSP we have eliminated the category of Beatitudes or Training Analysts chosen by their peers and any Analyst of the School can be chosen by a candidate as a supervising or control analyst.

An analyst is authorized by the desire that drives their formation rather than by the requirements of an institution. The others of a school are merely witnesses of the work the candidate analyst has accomplished. At LSP the analyst in formation is responsible to keep the record of how they have fulfilled the requirements of the school. Formation begins with a declaration to others of the subject's desire to be a psychoanalyst (what is called a Palimpsest) and concludes with a statement of their desire, on the basis of a record, to finish their formation. What we call the 'Passage', is the act of presenting a paper or case to the community and assume the name of Analyst of the School (an act of Nomination, therefore). In addition, they may speak to an analyst outside the school about their personal experience of the Unconscious in analysis.

At LSP we encourage candidates not only to participate in seminars but also to lead seminars in a state of suspended authority. This notion of suspended authority here means two things: (1) That the seminar leader shares the teaching seat with participants; and (2) That leading a seminar does not mean that the leader no longer takes seminars led by other analysts/candidates/faculty of the school. One of the potential pitfalls of this model is that a seminar may become a fiefdom/chiefdom or a way for the candidate to ascend through the ranks of the organization.

On the other hand, the school is not without the consequences of a meritocracy on the basis of the candidates own scholarly work and research as an end in itself. The analyst, more than being identified with a profession or with the name and gain associated with professional 
expertise, is a metaphor for the subject who knows about non knowing and unconscious knowing. In addition, by the same token that the analyst suspends the position or attitude of the master, a psychoanalytic school needs to be open and receptive to inborn and cultivated talent without invidious comparison to others. Such talent builds the reservoir of savoir of a school which is what Lacan was able to accomplish while running the risk of becoming the only voice and text of the school.

It should not be the sole responsibility of one single individual to create or dissolve a school. In addition, it is important to differentiate between constructive and destructive/nihilistic forms of emptying out or dissolving/changing a structure. As argued in previous chapters, structures are already empty, and are only reified by the impregnations of the ego, the master, and the Imaginary. The 'few others' of authorization represent the necessity of a demystified and barred Other (not a master institution) to function as a guarantee of the psychoanalytic organization as an open system subject to change and evolution, both positive and negative. This criterion may be more important than thinking that all organizations should be periodically dissolved and reinvented. In fact, Lacan's dissolution of his school, led to the establishment of a new organization that according to some has become even more undemocratic than the IPA. In addition, many alternative Lacanian organizations have sprung up that continue to exist to this day without being dissolved by their founders.

Finally, what is the difference between a study group, a cartel, a seminar, and a work group. Which one is a work group in the sense that Bion meant it? A study group can be a leaderless group but often has a leader that comments and expounds on a text being read. The cartel with the plus one is a way to combine both factors except that the plus one does not teach but rather assigns and coordinates the work tasks of the group. A cartel does not resolve the problem of the difference in talent and motivational desire among members of a group.

Leadership may still emerge within a group since a school is the work and talent that members bring to the school. However, talent here is not resolved in the direction of artificial intelligence or the intellectual power of computation and information within a binary system (like a robot or automaton who wants to be smarter than people or 


\begin{tabular}{|lll|l|}
\hline Layout: Pop_A5 & Book ID: 461782_1_En & Book ISBN: 978-3-319-94003-8 & Page: 251/256 \\
Chapter No.: 11 & Date: 19 June 2018 19:18 & (11 & \\
\hline
\end{tabular}

11 The Lacanian School as an Organizational Structure

902 other people). Talent ends in savoir or a form of unknown knowing 903 (linsu qui sait) that cancels out the ego ideal of the master and points 904 rather to the human subject of the Real that responds to and follows 905 from Tyche and Nous rather than automaton or a robot of instrumen906 tal/technical reason.

907

908

909

910

911

912

913

914

915

916

917

918

919

A seminar allows for the leadership of talent and effort while at the same time being a work group in the sense that the leader as an analyst functions as $S_{0}$ in a state of suspended (ego master) authority and shares the teaching seat with participants who can also present their work. In the work group, Bion accepted the leadership bestowed upon him by his own work and the group but used it in a different way according to a category of reason known as savoir in Lacan and knowing of $\mathrm{O}$ in Bion. The latter continues a tradition of mind in Western philosophy known as Nous from the pre-Socratics, through Aristotle, to Husserl's phenomenology and Heidegger, and the Frankfurt School. This transmission of mind is absent in the master's discourse and the university discourse and remains alive in the analytic tradition invented/discovered by Freud.

\section{References}

Arnaud, G. (2002). The Organization and the Symbolic: Organizational Dynamics Viewed from a Lacanian Perspective. Human Relations, 55, 691-716.

Arnaud, G. (2003). A Coach or a Couch? A Lacanian Perspective on Executive Coaching and Consulting. Human Relations, 56, 1131-1154.

Arnaud, G., \& Vanheule, S. (2007). The Division of the Subject and the

Organization: A Lacanian Approach to Subjectivity at Work. Journal of Organizational Change Management, 20, 359-369.

Beattie, T. (2013). Theology After Postmodernity: Divining the Void-A Lacanian Reading of Thomas Aquinas. Oxford and New York, NY: Oxford University Press.

Bicknell, M., \& Liefooghe, A. (2010). Enjoy Your Stress! Using Lacan to Enrich Transactional Models of Stress. Organization, 17, 317-330.

Bion, W. R. (1946). Leaderless Group Project. Bulletin of the Menninger Clinic, 10, 77-81. 


\begin{tabular}{|lll|}
\hline Layout: Pop_A5 & Book ID: 461782_1_En & Book ISBN: 978-3-319-94003-8 \\
Chapter No.: 11 & Date: $\mathbf{1 9}$ June 2018 19:18 & Page: 252/256 \\
\hline
\end{tabular}

252 R. Moncayo

Bion, W. R. (1961 [1948-1951]). Experiences in Groups. In Experiences in Groups and Other Papers (pp. 27-137). London: Routledge.

Bion, W. R. (1961 [1952]). Group Dynamics. In Experiences in Groups and Other Papers (pp. 139-191). London: Routledge.

Bion, W. R., \& Rickman, J. (1961 [1943]). Intra-group Tensions in Therapy: Their Study as the Task of the Group. In W. R. Bion (Ed.), Experiences in Groups and Other Papers (pp. 11-26). London: Routledge.

Bloom, P., \& Cederström, D. (2009). The Sky's the Limit: Fantasy in the Age of Market Rationality. Journal of Organizational Change Management, 22, 159-180.

Burrell, G. (1988). Modernism, Post Modernism and Organizational Analysis 2: The Contribution of Michel Foucault. Organization Studies, 9, 221-235. AQ7 Carter, P., \& Jackson, N. (2004). Gilles Deleuze and Felix Guattari. In S. Linstead (Ed.), Organization Theory and Postmodern Thought (pp. 105126). London, Thousand Oaks and New Delhi: Sage.

Caudill, D. S. (1997). Lacan and the Subject of Law: Toward a Psychoanalytic Critical Legal Theory. Atlantic Highlands, NJ: Humanities Press.

Cederström, C., \& Hoedemaekers, C. (Eds.). (2010). "Preface", Lacan and Organization (pp. xiii-xviii). London: MayFly Books.

Cho, K. D. (2009). Psychopedagogy: Freud, Lacan, and the Psychoanalytic Theory of Education. Basingstoke and New York, NY: Palgrave Macmillan.

Contu, A., Driver, M., \& Jones, C. (2010). Jacques Lacan with Organization Studies. Organization, 17, 307-315.

AQ10 Cooper, R. (1989). Modernism, Post Modernism and Organizational Analysis 3: The Contribution of Jacques Derrida. Organization Studies, 10, 479-502. AQ11 Costas, J., \& Taheri, A. (2012). 'The Return of the Primal Father' in Postmodernity? A Lacanian Analysis of Authentic Leadership. Organization Studies, 33, 1195-1216.

de Maré, P. B. (1985). Major Bion. In M. Pines (Ed.), Bion and Group Psychotherapy (pp, 108-113). London: Routledge \& Kegan.

AQ12

Driver, M. (2009a). From Loss to Lack: Stories of Organizational Change as Encounters with Failed Fantasies of Self, Work and Organization. Organization, 16, 353-369.

Driver, M. (2009b). Struggling with Lack: A Lacanian Perspective on Organizational Identity. Organization Studies, 30, 55-72.

Driver, M. (2009c). Encountering the Arugula Leaf: The Failure of the Imaginary and Its Implications for Research on Identity in Organizations. Organization, 16, 487-504. 
Driver, M. (2014). The Stressed Subject: Lack, Empowerment and Liberation. Organization, 21, 90-105.

Eissler, R. S. (1954). 106th Bulletin of the International Psycho-analytical Association. The International Journal of Psycho-analysis, 35, 267-290.

Etchegoyen, R. H., \& Miller, J. A. (1996). Silence brisé. Entretien sur le mouvement psychanalytique. Paris: Agalma.

Fotaki, M. (2009). Maintaining the Illusion of a Free Health Service in Post-socialism: A Lacanian Analysis of Transition from Planned to Market Economy. Journal of Organizational Change Management, 22, 141-158.

Freud, S. (1914). Remembering, Repeating and Working-Through (Further Recommendations on the Technique of Psycho-analysis, II). SE, XII, $145-156$.

Freud, S., \& Breuer, J. (1895). Studien über Hysterie, G. W., I, 75-312.

Glynos, J. (2011). On the Ideological and Political Significance of Fantasy in the Organization of Work. Psychoanalysis, Culture and Society, 16, 373-393.

Harding, N. (2007). On Lacan and the Becoming-ness of Organizations/ Selves. Organization Studies, 28, 1761-1773.

Harrison, T. (2000). Bion, Rickman, Foulkes and the Northfield Experiments: Advancing on a Different Front. London: Jessica Kingsley.

Hendrix, J. S. (2006). Architecture and Psychoanalysis: Peter Eisenman and Jacques Lacan. New York, NY: Peter Lang.

Jagodzinski, J. (2005). Music in Youth Culture: A Lacanian Approach. Basingstoke and New York, NY: Palgrave Macmillan.

Johnsen, R., \& Gudmand-Høyer, M. (2010). Lacan and the Lack of Humanity in HRM. Organization, 17, 331-344.

Jones, C., \& Spicer, A. (2005). The Sublime Object of Entrepreneurship. Organization, 12, 223-246.

Kenny, K. (2009). Heeding the Stains: Lacan and Organizational Change. Journal of Organizational Change Management, 22, 214-228.

King, P. (Ed.). (2003). Introduction: The Rediscovery of John Rickman and His Work. In No Ordinary Psychoanalyst: The Exceptional Contributions of John Rickman (pp. 1-68). London and New York, NY: Karnac Books.

Kosmala, K., \& Herrbach, O. (2006). The Ambivalence of Professional Identity: On Cynicism and Jouissance in Audit Firms. Human Relations, 59, $1393-1428$.

Lacan, J. (1976 [1949]). Règlement et doctrine de la commission de l'enseignement. In J.-A. Miller (Ed.), La scission de 1953. La communauté psychanalytique en France I (pp. 29-36). Paris: Navarin. 


\begin{tabular}{|lll|}
\hline Layout: Pop_A5 & Book ID: 461782_1_En & Book ISBN: 978-3-319-94003-8 \\
Chapter No.: 11 & Date: 19 June 2018 19:18 & Page: 254/256 \\
\hline
\end{tabular}

254 R. Moncayo

1012

1013

1014

1015

1016

1017

1018

1019

1020

1021

1022

1023

1024

1025

1026

1027

1028

1029

1030

1031

1032

1033

1034

1035

1036

1037

1038

1039

1040

1041

1042

1043

1044

1045

1046

1047

1048

1049

1050

Lacan, J. (1976 [1975]). Interventions dans la séance de travail sur 'Du plus une'. Lettres de l'École freudienne, 18, 219-229.

Lacan, J. (1982 [1980]). D’écolage. École de la cause freudienne-Annuaire et textes statutaires. Paris: ECF.

Lacan, J. (1988 [1953-1954]). The Seminar, Book I, Freud's Papers on Technique (J.-A. Miller, Ed., J. Forrester, Trans.). Cambridge: Cambridge University Press.

Lacan, J. (1990 [1963]). Introduction to the Names-of-the-Father Seminar. In J. Copjec (Ed.), Television/A Challenge to the Psychoanalytic Establishment (J. Mehlman, Trans., pp. 81-95). New York, NY: W.W. Norton.

Lacan, J. (1990 [1964]). Founding Act. In J. Copjec (Ed.), Television/A Challenge to the Psychoanalytic Establishment (J. Mehlman, Trans., pp. 97-106). New York, NY: W.W. Norton.

Lacan, J. (1990 [1980]). Letter of Dissolution. In J. Copjec (Ed.), Television/A Challenge to the Psychoanalytic Establishment (J. Mehlman, Trans., pp. 129131). New York, NY: W.W. Norton.

Lacan, J. (1994 [1964]). The Seminar, Book XI, the Four Fundamental Concepts of Psychoanalysis (J.-A. Miller, Ed., A. Sheridan, Trans.). Harmondsworth: Penguin.

Lacan, J. (1995 [1967]). Proposition of 9 October 1967 on the Psychoanalyst of the School (R. Grigg, Trans.). Analysis, 6, 1-13.

Lacan, J. (2000 [1947]). British Psychiatry and the War (P. Dravers \& V. Voruz, Trans.). Psychoanalytical Notebooks of the London Circle, 4, 9-33.

Lacan, J. (2006 [1953]). The Function and Field of Speech and Language in Psychoanalysis. In Écrits (B. Fink, Trans., pp. 197-268). New York, NY and London: W.W. Norton.

Lacan, J. (2006 [1956]). The Situation of Psychoanalysis and the Training of Psychoanalysts in 1956. In Écrits (B. Fink, Trans., pp. 384-411). New York, NY and London: W.W. Norton.

Lacan, J. (2006 [1958]). The Direction of the Treatment and the Principles of Its Power. In Écrits (B. Fink, Trans., pp. 489-542). New York, NY and London: W.W. Norton.

Lacan, J. (2006 [1962]). Kant with Sade. In Écrits (B. Fink, Trans., pp. 645668). New York, NY and London: W.W. Norton.

Lacan, J. (2006 [1968-1969]). Le Séminaire, Livre XVI, D'un Autre à l'autre, texte établi par J.-A. Miller. Paris: du Seuil.

Lacan, J. (2007 [1969-1970]). The Seminar, Book XVII, the Other Side of Psychoanalysis (J.-A. Miller, Ed., R. Grigg, Trans.). New York, NY and London: W.W. Norton. 


\begin{tabular}{|lll|}
\hline Layout: Pop_A5 & Book ID: 461782_1_En & Book ISBN: 978-3-319-94003-8 \\
Chapter No.: $\mathbf{1 1}$ & Date: $\mathbf{1 9}$ June 2018 19:18 & Page: 255/256 \\
\hline
\end{tabular}

11 The Lacanian School as an Organizational Structure

1051 Lacan, J. (2014 [1962-1963]). The Seminar, Book X, Anxiety (J.-A. Miller, Ed.,

1052

1053

1054

1055

1056

1057

1058

1059

1060

1061

1062

1063

1064

1065

1066

1067

1068

1069

1070

1071

1072

1073

1074

1075

1076

1077

1078

1079

1080

1081

1082

1083

1084

1085

1086

1087

1088

1089 A. Price, Trans.). Cambridge: Polity.

Letiche, H. (2004). Jean Baudrillard. In S. Linstead (Ed.), Organization Theory and Postmodern Thought (pp. 127-148). London, Thousand Oaks and New AQ16 Delhi: Sage.

Letiche, H., \& Essers, J. (2004). Jean-François Lyotard. In S. Linstead (Ed.), Organization Theory and Postmodern Thought (pp. 64-87). London, Thousand Oaks and New Delhi: Sage.

AQ17

Linstead, S., \& Thanem, T. (2007). Multiplicity, Virtuality and Organization: The Contribution of Gilles Deleuze. Organization Studies, 28, 1483-1501. AQ18 Miller, J. A. (Ed.). (1976). La scission de 1953. La communauté psychanalytique en France I. Paris: Navarin.

Miller, J. A. (Ed.). (1977). L'excommunication. La communauté psychanalytique en France II. Paris: Navarin.

Miller, P. A. (2007). Postmodern Spiritual Practices: The Construction of the Subject and the Reception of Plato in Lacan, Derrida, and Foucault. Columbus, OH: Ohio State University Press.

Milovanovic, D. (2003). Critical Criminology at the Edge: Postmodern Perspectives, Integration, and Applications. Boulder, CO: Lynne Rienner.

Moncayo, R. (2008). Evolving Lacanian Perspectives for Clinical Psychoanalysis: On Narcissism, Sexuation, and the Phases of Analysis in Contemporary Culture. London: Karnac Books.

Nobus, D. (2013a). That Obscure Object of Psychoanalysis. Continental Philosophy Review, 46, 163-187.

AQ20

Nobus, D. (2013b). What Are Words Worth? Lacan and the Circulation of Money in the Psychoanalytic Economy. Modern psychoanalysis, 38, 157-188.

Nobus, D. (2016). Esprit de Corps, Work Transference and Dissolution: Lacan as an Organizational Theorist. Psychoanalytische Perspectieven, 34(4), 355-378.

Reik, T. (1998 [1948]). Listening with the Third Ear. New York: Farrar, Straus and Giroux.

Roudinesco, E. (1997 [1993]). Jacques Lacan (B. Bray, Trans.). New York, NY and London: Columbia University Press.

Safouan, M. (2000). Jacques Lacan and the Question of Psychoanalytic Training. London: Macmillan.

Stavrakakis, Y. (2008). Subjectivity and the Organized Other: Between Symbolic Authority and Fantasmatic Enjoyment. Organization Studies, 29, 1037-1059. 
Van Haute, Ph. (2002 [2000]). Against Adaptation: Lacan's 'Subversion of the Subject'-A Close Reading (P. Crowe \& M. Vankerk, Trans.). New York, NY: Other Press.

Vanheule, S., Lievrouw, A., \& Verhaeghe, P. (2003). Burnout and Intersubjectivity: A Psychoanalytical Study from a Lacanian Perspective. Human Relations, 56, 321-338.

Vanheule, S., \& Verhaeghe, P. (2004). Powerlessness and Impossibility in Special Education: A Qualitative Study on Professional Burnout from a Lacanian Perspective. Human Relations, 57, 497-519.

Vidaillet, B. (2007). Lacanian Theory's Contribution to the Study of Workplace Envy. Human Relations, 60, 1669-1700.

Vidaillet, B., \& Gamot, G. (2015). Working and Resisting When One's Workplace Is Under Threat of Being Shut Down: A Lacanian Perspective. Organization Studies, 36, 987-1011. 


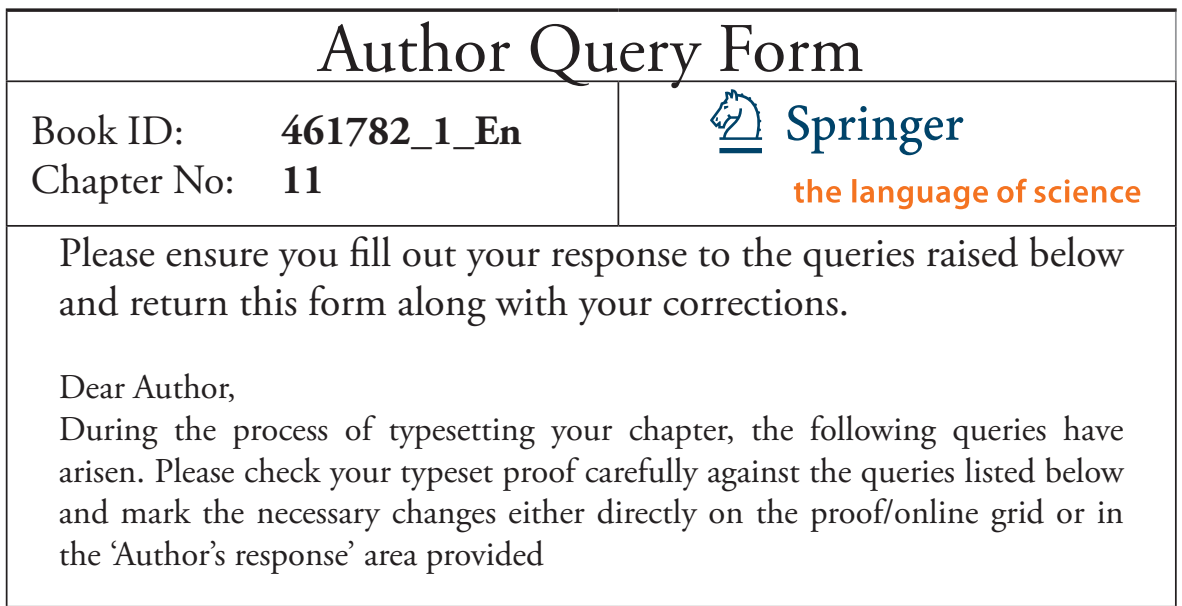

\begin{tabular}{|c|c|c|}
\hline Query Refs. & Details Required & Author's Response \\
\hline AQ1 & $\begin{array}{l}\text { The closing quote does not have a corresponding opening quote in } \\
\text { the sentence '....Psychiatry served to forge the ....' Please insert the } \\
\text { quote in the appropriate position. }\end{array}$ & \\
\hline AQ2 & $\begin{array}{l}\text { Reference 'Turquet (2014)' is cited in the text but not provided in } \\
\text { the reference list. Please provide the respective reference in the list or } \\
\text { delete the citation. }\end{array}$ & \\
\hline AQ3 & $\begin{array}{l}\text { The opening quote does not have a corresponding closing quote in } \\
\text { the sentence 'In the opening ... "[F] or a labor ....' Please insert the } \\
\text { quote in the appropriate position. }\end{array}$ & \\
\hline AQ4 & $\begin{array}{l}\text { The opening quote does not have a corresponding closing quote in } \\
\text { the sentence 'For example ... the 'subject supposed ..... Please insert } \\
\text { the quote in the appropriate position. }\end{array}$ & \\
\hline AQ5 & $\begin{array}{l}\text { Reference 'Lacan (1967)' is cited in the text but not provided in the } \\
\text { reference list. Please provide the respective reference in the list or } \\
\text { delete the citation. }\end{array}$ & \\
\hline AQ6 & $\begin{array}{l}\text { Reference 'Bion and Rickman }(1961[1943]) \text { ' is given in the list but } \\
\text { not cited in the text. Please cite this in text or delete this from the } \\
\text { list. }\end{array}$ & \\
\hline AQ7 & $\begin{array}{l}\text { Reference 'Burrell (1988)' is given in the list but not cited in the } \\
\text { text. Please cite this in text or delete this from the list. }\end{array}$ & \\
\hline AQ8 & $\begin{array}{l}\text { Reference 'Carter and Jackson (2004)' is given in the list but not } \\
\text { cited in the text. Please cite this in text or delete this from the list. }\end{array}$ & \\
\hline AQ9 & $\begin{array}{l}\text { Reference 'Cederström and Hoedemaekers (2010)' is given in the list } \\
\text { but not cited in the text. Please cite this in text or delete this from } \\
\text { the list. }\end{array}$ & \\
\hline AQ10 & $\begin{array}{l}\text { Reference 'Contu and Driver (2010)' is given in the list but not cited } \\
\text { in the text. Please cite this in text or delete this from the list. }\end{array}$ & \\
\hline
\end{tabular}




\begin{tabular}{|l|l|l|}
\hline Query Refs. & Details Required & Author's Response \\
\hline AQ11 & $\begin{array}{l}\text { Reference 'Cooper (1989)' is given in the list but not cited in the } \\
\text { text. Please cite this in text or delete this from the list. }\end{array}$ & \\
\hline AQ12 & $\begin{array}{l}\text { Reference 'de Maré (1985)' is given in the list but not cited in the } \\
\text { text. Please cite this in text or delete this from the list. }\end{array}$ & \\
\hline AQ13 & $\begin{array}{l}\text { Reference 'Freud and Breuer (1895)' is given in the list but not cited } \\
\text { in the text. Please cite in text or delete from the list. }\end{array}$ & \\
\hline AQ14 & $\begin{array}{l}\text { Reference 'King (2003)' is given in the list but not cited in the text. } \\
\text { Please cite in text or delete from the list. }\end{array}$ & \\
\hline AQ15 & $\begin{array}{l}\text { References 'Lacan (1990 [1980], 1994 [1964], 1995 [1967])' are } \\
\text { given in the list but not cited in the text. Please cite them in text or } \\
\text { delete them from the list. }\end{array}$ & \\
\hline AQ16 & $\begin{array}{l}\text { Reference 'Letiche (2004)' is given in the list but not cited in the } \\
\text { text. Please cite this in text or delete this from the list. }\end{array}$ & \\
\hline AQ17 & $\begin{array}{l}\text { Reference 'Letiche and Essers (2004)' is given in the list but not } \\
\text { cited in the text. Please cite this in text or delete this from the list. }\end{array}$ & \\
\hline AQ18 & $\begin{array}{l}\text { Reference 'Linstead and Thanem (2007)' is given in the list but not } \\
\text { cited in the text. Please cite this in text or delete this from the list. }\end{array}$ & \\
\hline AQ19 & $\begin{array}{l}\text { Please check if the inserted publisher name and location for the } \\
\text { reference 'Moncayo (2008)' is correct. }\end{array}$ & \\
\hline AQ20 & $\begin{array}{l}\text { References 'Nobus (2013a, b, 2016)' are given in the list but not } \\
\text { cited in the text. Please cite them in text or delete them from the list. }\end{array}$ & \\
\hline
\end{tabular}

